\title{
Penggunaan Play Therapy dalam Mengurangi Rasa Trauma Anak yang Mengalami Kekerasan Seksual
}

\author{
Lia Mita Syahri ${ }^{1}$, Ifdil ${ }^{2}$ \\ Universitas Negeri Padang ${ }^{1}$, Universitas Negeri Padang ${ }^{2}$ \\ *) Correspondence Author, e-mail: Liaasyahri@yahoo.com ifdil@konselor.org
}

\begin{abstract}
Permasalahan ini dilatar belakangi oleh banyak terjadi kasus kekerasan seksual yang bukan hanya terjadi kepada orang dewasa, akan tetapi saat sekarang ini kasus kekerasa seksual juga terjadi pada anak-anak yang masih dibawah umur, dimana pelaku kejahatan dari kekerasan seksual tersebut adalah orang dewasa bahkan bisa jadi orang terdekat mereka yang mereka anggap sebagai pelindung bagi mereka. Kekerasa seksual yang mereka dapatkan dilakukan oleh pelaku dari kekerasan seksual dengan cara memberikan iming-iming kepada anak tersebut dengan membelikannya permen atau es cream sehingga anak tersebut mengikuti kemauan dari pelaku kekerasan seksual, pelaku kekeresan seksual pada anak-anak lebih dikenal dengan tindakan atau penyakit yang disebut "Pedofil" dimana pelaku pedofilia ini lebih menyukai anak-anak dalam meluapkan hawa nafsu seksual nya ketimbang kepada orang dewasa. Anak-anak yang mengalami kekerasa seksual mereka akan mengalami rasa takut atau trauma yang amat mendalam baik luka atau trauma yang ditinggalkan melalui fisik atau berupa luka pada bagian tubuh mereka yang menjadi obsek kepuasaan seksual atau trauma (luka) pada bagian psikologis mereka berupa rasa takut dan tidak percaya kepada siapapun atau pun rasa yang mereka sendiri sebagai anak-anak tidak mengerti apa yang telah terjadi pada diri mereka, sehingga kejadian yang mereka alami yaitu kekerasan seksual yang mereka dapatkan akan menganggu fikiran mereka, anak-anak akan rentan lebih lama mengingat kejadian tersebut, sehingga dalam hal ini teknik play therapy (Terapi bermain) dalam play therapy kegiatan utama yang dilakukan adalah bermain, maka dari itu diharapkan dalam penggunaan play therapy anak-anak yang mengalami kejadian kekerasan seksual dapat kembali ke dunianya yaitu bermain dan dapat melupakan kejadian kekerasan seksual yang mereka rasakan, anak-anak kembali dalam kegiatannya bermain dan kembali lagi percaya kepada lingkungan mereka yang dapat menjaga mereka dari kejadian yang menyakitkan.
\end{abstract}

Keywords: Kekerasan Seksual, Play Therapy

Article History: Received on 15/05/2019; Revised on 15/06/2019; Accepted on 12/07/2019; Published Online: $15 / 07 / 2019$. distribution, and reproduction in any medium, provided the original work is properly cited. ( 2019 by author.

\section{PENDAHULUAN}

Kasus kekerasan seksual akhir-akhir ini menjadi kasus yang sudah tidak asing lagi didengar, banyak terjadi kasus kekerasan seksual di lingkungan sekitar, dimulai dari orang dewasa, orangtua bahkan lansia dan ada anak-anak yang menjadi korban dari kejahatan kekerasan seksual, anak-anak yang kegiatannya adalah bermain dan 
dilindungi, dalam hal ini dijadikan sebagai objek pemuas nafsu seksualitas bagi pihakpihak yang tidak memiliki kemanusiaan dan tidak bertanggung jawab atas tindakan yang sudah mereka lakukan, bahkan anak-anak yang masih dibawah umur yang berkemungkinan tidak mengerti apa itu seksual atau kegaiatan seksualitas dijadikan sebagai objek pemenuhan kebutuhan seksual. Sehingga anak-anak yang menjadi korban kekerasan seksual akan mengalami trauma atau rasa takut akibat kejadian yang mereka alami, kejadian yang mereka sendiri tidak mengetahui apa dan dampak yang akan mereka rasakan setelah mendapatkan perlakuan kekerasan seksual, maka dari itu dengan adanya teknik bermain atau play therapy yang disesuikan dengan tugas anak-anak yaitu bermain, maka keadaan psikologis anak atau rasa takut anak dapat disalurkan melalui kegiatan bermain yang memiliki bermacam-macam permainan yang ada, dengan banyaknya pilihan mainan yang bisa digunakan oleh anak-anak maka diharapkan dapat diketahui bagaimana bentuk kronologis yang dirasakan oleh anak-anak kasus kekerasan seksual melalui permainan yang mereka mainkan atau mereka pilih, dengan adanya permainan yang disenangi atau digemari oleh anak-anak maka diharapkan rasa takut atau trauma secara psikologis yang dirasakan oleh anak-anak dapat berkurang atau tergantikan dengan perasaan bahagia atau senang karena bermain yang anak-anak lakukan, sehingga anak-anak korban kekerasan seksual kembali percaya lagi dengan orang-orang disekitar mereka dan dapat bersosialisasi tanpa ada rasa takut atau khawatir kejadian yang sama terulang lagi kepada mereka.

(Fauzi'ah, 2016) kekerasan atau pelecahan seksual yang dirasakan oleh anak-anak yaitu anak-anak dibuat tidak merasakan rasa aman pada diri mereka, bagi si pelaku kekerasan seksual, anak-anak yang menjadi objek pemuas nafsu seksualitasnya akan diajak berbicara atau membicarakan hal-hal yang berbau dengan seksualitas, dengan cara diberikan hadiah atau benda bahkan makanan kesukaan mereka, setelah mereka mendapatkan makanan atau benda yang disukai oleh anak-anak, maka si pelaku akan mengajak anak-anak melakukan hubungan seksualitas, dengan berbagai cara, ada anakanak yang dipaksa atau diancam agar mau melakukan apa yang diminta oleh si pelaku, dan lebih kasarnya setelah anak-anak dijadikan objek pemuas nafsu, anak tersebut diancam kembali dengan cara yang keras agav tidak memberitahukan kepada siapapun apa yang telah mereka alami.

Dalam penelitian (Maslihah, 2013) kekerasan seksual yang terjadi pada anak-anak $70 \%$ pelakunya adalah orang-orang terdekat atau yang mereka percayai akan melindungi mereka dari kejahatan. Maka dari itu tindakan kekerasan seksual yang dialami oleh anakanak yang pelakunya adalah keluarga mereka sendiri akan memiliki kesulitan tersendiri dalam mengatasi rasa trauma yang mereka rasakan.

Ada beberapa kesulitan dalam menggunakan play therapy untuk mengungkapkan kronologis atau kejadian dari kekerasan seksual yang anak-anak alami, rasa trauma atau takut yang mereka alami akan membuat mereka takut dalam bermain, ada beberapa mereka yang mungkin saja di iming-imingi dengan permainan untuk mau melakukan seksual akan kesulitan menggunakan play therapy, keterbatasan umur bagi anak-anak juga mengalami kesulitan dalam menjelaskan bagaimana teknik bermain, maka dari itu maksud dari penggunaan play therapy untuk menghilangkan rasa trauma yang anak- 
anak alami yakni mengembalikan kegiatan anak dan rasa percaya mereka dengan lingkungan sekitar dengan cara bermain.

\section{PENGGUNAAN TEKNIK PLAY THERAPY DALAM MENGURANGI RASA TRAUMA ANAK YANG MENGALAMI KEKERASAN SEKSUAL Konsep Play Therapy}

Play Therapy merupakan teknik yang digunakan untuk dapat mengungkapkan berbagai keadaan perasaan atau menghilangkan suatu hal yang menganggu fikiran khususnya bagi anak-anak yang lingkungan atau tugasnya adalah bermain. (Mashar, 2011) therapy atau terapi bermain yang digunakan untuk menghilangkan rasa takut atau trauma bagi anak-anak, memiliki maksud atau tujuan agar anak dapat mengkomunikasikan perasaannya kepada orang dewasa, atau menyampaikan pesan yang tidak dapat disampaikan secara langsung oleh anak karena rasa takut atau trauma yang mereka alami, berbagai macam pilihan permainan yang dapat digunakan oleh anak, maka setiap permainan yang anak mainkan memiliki makna tersendiri atau simbolis keadaan anak atau hal yang anak-anak rasakan secara psikologisnya.

Menurut Sukmanigrum (dalam, Sholihat \& Nasrullah, 2018)penggunaan play therapy dapat membantu anak mengungkapkan, mengkomunikasikan, mengeksplorasikan keadaan perasaan mereka secara terbuka kepada lingkungan sekitar dengan menggunakan alat peraga permainan yang mereka pilih.

Menurut Sholihat \& Nasrullah, (2018) kegunaan play therapy dapat menghilangkan atau melupakan rasa trauma atau suatu kejadian yang mereka rasakan, dengan bermain anak-anak dapat melupakan kejadian kekerasan seksual yang mereka alami, dapat percaya dengan lingkungan mereka dan kembali bersosialisasi dengan lingkungan sekitar.

Selanjutnya menurut (Hatiningsih, 2013) permainan bagi anak-anak adalah suatu aktivitas yang mereka lakukan dalam rangka mengekspresikan perasaan meveka, dalam permainan yang mereka pilih ada pesan khusus yang ingin mereka sampaikan tentang diri mereka kepada lingkungan sekitarnya, walaupun dalam kaidahnya bahasa permainan itu tidak baku, tapi bagi anak-anak yang memiliki rasa takut atau trauma, melalui permainan anak akan menceritakan kejadian yang mereka alami. Schaefer (dalam Hatiningsih, 2013) Play Therapy merupakan kegiatan yang bukan sekedar hanya bermain, akan tetapi dalam permainan dan alat permainan yang digunakan oleh anakanak, memiliki maskud dan pesan berupa keadaan perasaan anak, terutama bagi anakanak yang memiliki perasaan trauma, dengan adanya permainan yang dapat dimainkan oleh anak-anak, anak-anak yang memiliki trauma akan dapat mengkomunikasikan peristiwa trauma yang mereka rasakan, setelah itu anak akan dapat melupakan secara perlahan rasa takut akibat trauma yang mereka rasakan dan anak akan kembali ke dunianya yaitu dunia bermain bagi anak-anak.

Manfaat Penggunaan Teknik Play Therapy

Menurut (Indrawati, Mamesah, \& Putri, 2018) beberapa manfa'at dalam menggunakan Play Therapy adalah: 
1. Play therapy dapat mengungkapkan bagaimana perkembangan, keadaan psikologis dan perasaan yang dirasakan oleh anak-anak melalui pemainan yang mereka pilih

2. Meningkatkan daya imajinasi, kreatiivitas, sosialisasi, saling rasa percaya dan keterbukaan pada anak terhadap lingkungan sekitar melalui media permainan

3. Memudahkan konselor dalam melakukan pendekatan dan membaca situasi atau memahami keadaan anak secara psikologis, melalui permainan yang digemari oleh anak.

Senada dengan hal tersebut menurut (Aqib, 2014) beberapa manfa'at dalam menggunakan Play Therapy adalah:

1. Bagi anak, dengan adanya kegiatan bermain, maka rasa menyenangkan dan rasa kegembiraan yang dirasakan oleh anak, sehingga rasa cemas, takut akan trauma yang mereka alami dapat mereka lupakan. Setiap permainan yang dipilih oleh anak-anak, memiliki maksud dan tujuan dari permainan yang mereka lakukan

2. Dengan bermain anak dapat mengungkapkan sebuah pesan dengan berani tanpa ada rasa takut dan dapat meningkatkan rasa percaya diri mereka dengan lingkungan sosialnya.

3. Meningkatkan hubungan suasanan yang bahagia dan sehat dengan sekitarnya

4. Menumbuhkan jiwa kreativitas pada anak sa'at bermain

5. Dengan ada banyaknya pilihan permainan yang dapat mereka gunakan, maka anak dapat kembali menyesuaikan diri dengan lingkungan sekitarnya.

Banyak manfa'at yang dapat dirasakan oleh anak dalam melaksanakan terapi atau teknik play therapy, hal yang paling utama yang dapat dirasakan oleh anak yakni, anak mampu mengekspresikan dirinya, melatih anak bersosialisasi dan mengungkapkan atau mengkomunikasikan bagaimana perasaan psikologis anak dan bahkan anak bisa menjadi pribadi yang kreatif dan memiliki hubungan sosial yang baik dengan lingkungannya. Rasa aman dan percaya yang dapat dimunculkan dalam bermain, menjadikan anak pribadi yang menyenangkan, merasa aman bermain dengan lingkungannya, sehingga rasa takut atau trauma pada anak dapat dilupakan atau bahkan hilang dalam memori ingatan anak.

Bentuk Pendekatan Play Therapy

Menurut Labauve dkk (dalam Zellawati, 2011) ada beberapa bentuk pendekatan terapi bermain yaitu:

1. Model Alderian: Penggunaan model Adler yaitu lebih menekankan kepada interaksi dalam berhubungan sosial, dalam hal ini fokus utama bagi anak-anak adalah mereka dapat membangun pola hubungan sosial dengan interkasi atau komunikasi yang baik dengan lingkungan sekitarnya.

2. Model terapi Clien-Centered: sesuai dengan teori Rogers, kembali menumbuhkan aktualisasi diri pada anak-anak, khususnya anak-anak yang memiliki rasa trauma atau cemas, takut terhadap suatu peristiwa. 
3. Model Kognitif-Behavioral: sama halnya antara anak-anak dan orang dewasa yang memiliki pemikiran sendiri tentang dirinya, maka dari itu penggunaan model ini ditunjukkan bagi anak-anak yang memiliki pemikiran irrasional terhadap dirinya sehingga mereka melakukan tingkah laku yang menyimpang atau disebut maladaptive

4. Model Ekosistemik: menekankan pada interaksi anak dengan lingkungannya

5. Model Eksistensialisme: model ini lebih menekankan bahwa keunikan yang ada pada diri anak, maka dari itu kegiatan bermain yang dilakukan oleh anak-anak adalah agar keunikan dari anak tersebut tetap ada dan terjaga.

6. Model Gestalt: model ini dibuat untuk membantu pertumbuhan atau perkembangan anak.

7. Model Jungian: digunakan untuk memperbaiki keadaan ego anak agar mereka dapat kembali seimbang dan menghilangkan ketidakstabilan mereka dalam menampilkan fungsi ego mereka sebagai anak-anak.

\section{Kekerasan Seksual}

Menurut Penelitian Sutrisno (dalam Zakki, 2017) kasus kekerasan seksual sering terjadi di Indonesia, 67,8\% kasus kekerasan seksual sering terjadi dengan objek seksualitasnya yaitu anak-anak. Diperjelas lagi oleh Annisa (dalam Zakki, 2017) pelecehan seksual atau kekerasan seksual merupakan suatu tingkah laku seksualitas yang tidak diharapkan oleh sasaran seksualnya, sehingga sering kali korban dari pelecahan atau kekerasan seksual merasa malu, takut, marah dan trauma akibat kejadian yang menimpa mereka, dalam kasus lainnya kekerasan seksual yang mereka alami berupa tindakan si pelaku yang memaksa korban untuk memenuhi kebutuhan seksualitas nya dengan cara memaksa atau berupa ancaman agar korban mau melakukannya, sehingga rasa kasihan atau belas kasih tidak ada pada diri pelaku, yang ada hanya bagaimana cara kebutuhan seksual pada si pelaku dapat terlampiaskan kepada si korban.

Selanjutnya menurut (Maslihah, 2013) kekerasan seksual pada anak artinya kejahatan seksualitas yang dilakukan oleh si pelaku menjadikan anak-anak sebagai objek pemenuh kebutuhan seksualitasnya, rata-rata anak-anak yang menjadi objek tersebut adalah anak yang masih dibawah umur dan tidak mengerti mengenai seksualitas. Kekerasan seksual yang terjadi pada anak menurut Lyness (dalam dalam, Maslihah, 2013) suatu tindakan yang dilakukan kepada anak seperti mencium atau memainkan organ kelamin anak, memperlihatkan video porno kepada anak, atau menjadikan alat kelamin anak sebagai tempat pemuasan kebutuhan seksualitas secara paksa kepada anak. Kemudian diperjelas lagi oleh (Fauzi'ah, 2016) kekerasan seksual yang dilakukan kepada anak, berupa pemenuhan seksualitas si pelaku, memaksa anak untuk mengikuti apa yang diinginkan si pelaku, memperlihatkan video porno kepada anak, dan mengancam anak agar mau melakukannya, itu semua merupakan suatu tindakan yang dapat membahayakan psikologis dan fikiran anak yang tentunya akan dapat mengancam masa depan anak.

Maka dari itu bedasarkan penelitian yang dilakukan (Fauzi'ah, 2016) bahwa pelecehan seksual dengan tindakan kekerasan pada anak, sering terjadi di Indonesia, 
pelaku dari kekerasan seksual yang terjadi pada anak rata-rata adalah mereka yang merupakan keluarga dekat bagi anak, yang menurut anak dapat melindungi dan mereka percaya, salah satu factor tingkat kekerasan seksual mudah terjadi pada anak karena salah satunya pelaku adalah orang terdekat anak, sehingga anak mau mengikuti apa yang diperintahkan oleh pelaku. Akhir-akhir ini kasus kekerasan seksual pada anak sering terjadi dan dalam hal ini kasus ini disebut dengan penyakit atau kelainan yaitu "pedofil"

\section{Bentuk Pelecehan Seksual Pada Anak}

Menurut (Fauzi' ah, 2016) bentuk pelecehan seksual pada anak berupa:

1. Incest: dalam permasalahan ini, pelaku utama dari kekerasan seksual bagi anak adalah keluarga dekatnya seperti ayah kepada anak perempuan atau paman kepada keponakan perempuan atau sebaliknya.

2. Extrafamilial Sexual Abuse: pelaku kekerasan seksual berasal dari lingkungan luar anak, seperti orang asing yang tidak dikenal oleh anak, dengan cara membujuk anak dengan makanan atau benda-benda yang disukai oleh anak.

3. Bisnis Seks Komersial Pornografi: kekerasan seksual pada anak berupa, membuat atau memperdagangkan video porno sebagai anak dibawah umur sebagai objek utama videonya, bahkan dalam video tersebut, anak-anak melakukan hubungan intim seperti layaknya pasangan suami istri, video ini akan memunculkan hawa nafsu atau syahwat yang semakin meninggi bagi pelaku pedofil dan akan mencari anak-anak dibawah umur untuk menyalurkan seksualnya yang tidak tertahankan.

\section{Penggunaan Play Therapy dalam mengurangi Trauma Anak Kasus Kekerasan Seksual}

Menurut Huda dkk (dalam Alhadi, 2016) Play therapy mampu mengatasi permasalahan secara psikologis terhadap anak-anak yang mengalami rasa trauma atau takut dengan suatu peristiwa, dengan fokus utamanya yaitu bermain, sesuai dengan perkembangan anak-anak yang kegiatannya bermuara akhir dalam bermain, maka melalui media permainan yang berbagai macam, anak akan menyalurkan rasa takut atau cemasnya melalui media permainan tersebut, anak akan mampu mengkomunikasikan peristiwa yang dialaminya, dan sedikit demi sedikit semua perasaan takut anak akan terluapkan dan anak akan mudah melupakan kejadian yang membuat anak trauma, sehingga anak kembali bersosialisasi, mempercayai lingkungan sekitarnya secara aman dan nyama atau terbuka dalam berhubungan dengan oranglain.

Selanjutnya Cattanach (dalam Alhadi, 2016) dalam penggunaan play therapy, keseluruhan media permainan yang dipilih oleh anak adalah media permainan yang disenangi atau diinginkan oleh anak dalam meluapkan emosi yang dimiliki oleh anak, maka dalam hal ini konselor dapat membaca pesan khusus yang disampaikan oleh anak lewat permainan yang dilakukan oleh anak terutama bagi anak-anak yang memiliki perasaan takut atau trauma akibat tindakan kekerasan seksual, anak akan menceritakan segala keadaan perasaan yang ada dalam hatinya terkait kejadian yang menakutkan baginya, atau bercerita dengan boneka terkait kekerasan seksual yang dirasakan oleh anak, maka dari itu melalui kegiatan tersebut, konselor dapat melakukan pendekatan emosional dengan anak untuk mengetahui apa yang terjadi pada anak dan melakukan konseling dengan anak untuk mengurangi rasa trauma yang anak rasakan. 
Penggunaan play therapy dihavapkan keadaan psikologis anak yang senang bermain atau berinteraksi dengan lingkungan sekitar, menjadi anak yang periang dan bahagia, melalui media permainan maka anak-anak yang menjadi korban kekerasan seksual dapat mengurangi rasa trauma atau takutnya terhadap kejadian kekerasan seksual yang mereka rasakan, anak dapat menjadi kembali seperti sifat dan perkembangan anak-anak yang bahagia, dan sedikit demi sedikit dapat menghilangkan rasa cemas secara psikologis akibat kekerasan seksual yang mereka alami.

Play therapy yang digunakan atau media yang digunakan tentu disesuaikan dengan umur anak dan keadaan perkembangan anak yang menajdi korban kekerasan seksual, sehingga pengungkapkan kasus keekrasan seskual pada anka dapat menemukan solusi atau pemecahan masalah, terutama menghilangkan ras curiga, khawatir, takut atau perasaan trauma bagi anak yang mengalami kekerasan seksual, dan juga dilihat serta dianalisa bentuk kekerasan seksual yang mereka rasakan.

\section{KESIMPULAN}

Penggunaan Play Therapy dapat dikatakan baik digunakan dalam menyelesaikan kasus trauma bagi anak-anak yang menjadi korban kasus kekerasan seksual, dengan sikap naluri anak yang menyukai aktivitas mengenai bermain, maka dengan memanfaatkan kesukaan pada anak tersebut konselor dapat mengungkapkan bagaimana keadaan psikologis anak atau bagaimana trauma yang dirasakan oleh anak melalui kegiatan bermain yang dilakukan oleh anak.

Anak dapat mengkomunikasikan atau mengekspresikan segala hal yang mereka fikirkan atau rasakan pasca kejadian kekerasan seksul yang dialami oleh anak, dengan cara itu anak mengkomunikasikan dan dapat memudahkan konselor mengetahui bagaimana keadaan anak, karena dalam menjelaskan tidak akan mudah bagi anak menjelaskan dengan kat-kata langsung, karena keterhambatan kosa kata anak, sementara saling kita ketahui bahwa periode anak yang dibawah umur yang rentan menjadi korban kasusu kekerasan seksual masih dalam perkembangan mengenali bahasa atau berupaya merangkai bahasa untuk berbicara, sehingga penggunaan play therapy sangat efektif dalam menyelesaikan kasus permasalahan pada anak korban kasus kekerasan seksual.

Dan juga dengan play therapy atau terapi bermain di selingi dengan observasi dan wawancara secara aman dan terbuka bagi anak, maka memudahkan konselor dalam mengetahui bagaimana kronologis terjadinya kasus kekerasan seksual itu, setiap bahasa atau hal yang dikatakan anak yang memiliki trauma terhadap kejadian kekerasan seksual tersebut maka akan mengetahui bagaimana sebenarnya bisa terjadi kasus kekerasan seksual tersebut.

\section{REFERENCES}

Alhadi, S. (2016). Play Therapy: Sebuah Inovasi Layanan Konseling Bagi Anak Usia Dini. Jurnal CARE (Children Advisory Research and Education), 3(3), 52-57.

Aqib, Z. (2014). Peningkatan Profesionalitas Guru Untuk Mengentaskan Masalah Siswa Dengan Teknik Assosiasi Bebas Dan Play Therapy Dalam Konseling Kelompok Di Smk Muhammadiyah 1 Berbek Kab. Nganjuk. Wahana, 62(1). 
Fauzi'ah, S. (2016). Faktor penyebab pelecehan seksual terhadap anak. An-Nisa', IX, 2, 81101.

Hatiningsih, N. (2013). Play therapy untuk meningkatkan konsentrasi pada anak attention deficit hyperactive disorder (ADHD). Jurnal Ilmiah Psikologi Terapan, 1(2), 324342.

Indrawati, S. A., Mamesah, M., \& Putri, A. P. (2018). Penerapan Cognitive Behavioral Play Therapy untuk Anger Expression pada Anak. INSIGHT: Jurnal Bimbingan Konseling, 7(1), 9-23.

Mashar, R. A. (2011). Play Therapy Dalam Kelompok Guna Meningkatkan Emosi Positif Anak Usia Dini. Makalah diisampaikan dalam Seminar dan Workshop Internasional di Universitas ....

Maslihah, S. (2013). Play therapy dalam identifikasi kasus kekerasan seksual terhadap anak. Jurnal Penelitian Psikologi, 4(1).

Sholihat, I., \& Nasrullah, D. D. (2018). Konseling pada anak korban bencana alam: play therapy perspektif. In Seminar Nasional Bimbingan dan Konseling Jambore Konseling 3. Ikatan Konselor Indonesia (IKI).

Zakki, N. A. dan E. P. (2017). Play Therapy Art Expression Media Menggambar Untuk Mengurangi Stress Anak Jalanan Korban Pelecehan Seksual. Jurnal Bimbingan Dan Konseling Islam.

Zellawati, A. (2011). Terapi bermain untuk mengatasi permasalahan pada anak. Majalah Ilmiah Informatika, 2(3) 